\title{
Currency Board da Argentina: os laços que unem?
}

\author{
Argentina's currency board: what keep them together?
}

CAROL WISE *,*

RESUMO: Como o único país de mercado emergente da América Latina que aderiu firmemente a uma taxa de câmbio fixa por mais de uma década, este artigo examina as compensações econômicas e políticas que a paridade peso-dólar acarretou. Em termos econômicos, o conselho da moeda promoveu claramente a estabilidade macroeconômica e a prudência fiscal. No entanto, a manutenção de um regime de moeda fixa no contexto de fluxos voláteis de capital também contribuiu para a constante valorização do peso ao longo do tempo. Essa tendência, juntamente com certos acordos políticos (lenta reforma do mercado de trabalho e transferências generosas do governo para as províncias) ocorridas no início do programa de reformas, dificultou bastante a produtividade e o dinamismo da economia argentina. A fraca posição competitiva do país foi exacerbada pela desvalorização brasileira de 1999, e a lição desde então tem sido o quão difícil é formar uma coalizão política para enfrentar as formidáveis tarefas microeconômicas agora em mãos.

PALAVRAS-CHAVE: Currency board; dolarização; inflação.

ABSTRACT: As the one Latin American emerging market country that has steadfastly adhered to a fixed exchange rate for more than a decade, this article examines the economic and political trade-offs that peso-dollar parity has entailed. In economic terms, the currency board has clearly fostered macroeconomic stability and fiscal prudence. Yet, the maintenance of a fixed currency regime in the context of volatile capital flows has also contributed to the steady appreciation of the peso over time. This trend, along with certain political deals (slow labor market reform and generous government transfers to the provinces) struck at the outset of the reform program, has greatly hampered the productivity and dynamism of the Argentine economy. The country's weak competitive position has been exacerbated by the Brazilian devaluation of 1999, and the lesson since then has been how difficult it is to craft a political coalition to tackle the formidable microeconomic tasks now at hand.

KEYWORDS: Currency board; dollarization; inflation.

JEL Classification: F31; F33.

\footnotetext{
* Associate Professor of Political Economy at Johns Hopkins University - SAIS, Baltimore/MD, U.S.A. E-mail: cwise@E-mail.usc.edu.

** A pesquisa de base para este capítulo teve o apoio do Centro Norte-Sul da Universidade de Miami, do Instituto de Paz dos Estados Unidos e da Comissão Fulbright, em Buenos Aires. A autora agradece a John Hipp por sua coleta e análise de dados, assim como a Issac Cohen, Max Corden, Carol Graham, Randy Henning, Tim Kessler, Maureen Molot, Ron Scheman, Judith Teichman e a dois revisores anônimos por seus comentários tão úteis nos rascunhos iniciais. Tradução de Rosiléa Pizarro Carnelós.
} 
Desde meados dos anos 80, todos os países de mercado emergente da América Latina, com exceção da Argentina, migraram de regimes de taxas cambiais fixas, que fixavam a moeda interna a uma ou várias moedas estrangeiras, para regimes mais flexíveis, sob os quais o valor da moeda é determinado mais ou menos pela oferta e demanda desta no mercado. Além da Argentina, são os menores Estados do Caribe (tais como Barbados, Dominica e Granada) e da América Central (Panamá, por exemplo) que continuam a aderir a regimes de taxas de câmbio fixas. ${ }^{1}$ Essa tendência no hemisfério ocidental reflete o mundo em desenvolvimento em geral: em 1996 os países com taxas fixas eram responsáveis por apenas 2\% do comércio total do mundo em desenvolvimento, comparando-se com 70\% em 1975.

Embora autoridades e acadêmicos ainda continuem debatendo ativamente sobre o regime cambial mais apropriado, essas tendências, até certo ponto, falam por si mesmas. Por que, então, a Argentina, com seu grande mercado emergente, continuou invariavelmente comprometida, desde 1991, com seu regime cambial fixo, mais comumente associado a economias pequenas, abertas, que não têm a capacidade de administrar uma política monetária independente de seus parceiros comerciais? Considerando-se o papel central atribuído às taxas de câmbio flexíveis no pacote de reforma de mercado, defendido pelo "Consenso de Washington", a situação de resistência da Argentina é duplamente difícil, porque é um país que também procurou seguir à risca as prescrições de Washington. ${ }^{2}$

São ambíguos os debates sobre as taxas de câmbio fixas contra as taxas flexíveis: um lado apresenta forte justificativa para adoção de uma taxa de câmbio fixa pela Argentina, enquanto o outro é igualmente convincente quanto à necessidade de mudar para um regime mais flexível. ${ }^{3} \mathrm{O}$ que está em jogo é a questão de como um país pode promover melhor o crescimento, a produtividade e os ganhos com receita; resistir a choques externos e manter um equilíbrio nos pagamentos internacionais e minimizar os custos do ajuste em termos de produção, emprego e inflação. Como Max Corden observa em seu capítulo, a defesa de uma moeda fixa se dá quando um país perdeu toda a credibilidade em dar sinais de um compromisso estrito com inflação baixa e disciplina macroeconômica. Quando as perturbações que recaem sobre uma economia são predominantemente monetárias, uma taxa cambial "ancorada", que fixa a moeda à de um outro país com uma história de inflação baixa, pode ser a única maneira de estabelecer a credibilidade necessária. Era pre-

\footnotetext{
${ }^{1}$ Francesco Caramazza e Jahangir Aziz, Fixed or Flexible? Getting the Exchange Rate Right in the 1990s (International Montary Fund, 1998), pp. 16-7.

${ }^{2}$ Sobre o papel das taxas de câmbio flexíveis no pacote de reforma de Washington, ver John Williamson, "The Progress of Policy Reform in Latin America", in John Williamson, org., Latin American Adjustment: How Much Has Happened? (Institute for International Economics, 1989), pp. 369-72.

${ }^{3}$ Estes debates estão revistos in W. Max Corden, Economic Policy, Exchange Rates, and the International System (University of Chicago Press, 1994 ); Ricardo Hausmann et al., "The Exchange Rate Debate", Latin American Economic Policies, vol. 7 (2 ${ }^{\circ}$ bimestre 1999), pp. 1-10; e Richard J. Sweeney, Clas G. Wihlbor, e Thomas D. Willett, orgs., Exchange Rate Policies for Emerging Market Economies (Boulder: Westview Press, 1999)
} 
cisamente essa a situação em que se encontrava a Argentina quando o governo lançou o Plano de Convertibilidade, em abril de 1991. Quando as taxas mensais de inflação repentinamente pularam de uma faixa de $20 \%$ a $30 \%$, no final dos anos 80, para 90 a 200\%, em 1989-1990, o governo do presidente Carlos Menem tinha pouca escolha a não ser seguir uma das estratégias que mais podiam estimular a credibilidade, disponíveis a um país no penoso processo de hiperinflação: um currency board. ${ }^{4}$ Sob o currency board, o peso argentino foi fixado em um para um com relação ao dólar americano, e foi estabelecida a convertibilidade total entre as duas moedas. Ao mesmo tempo, os poderes irrestritos de financiamento do Banco Central da Argentina foram drasticamente reduzidos, e o Banco teve que manter as reservas estrangeiras, totalizando $100 \%$ da base monetária nacional. O Plano de Convertibilidade efetivamente atou as mãos das autoridades nacionais, já que o currency board mudou o ônus da responsabilidade pela política monetária e, numa extensão menor, mudou a restrição fiscal para o setor externo.

Esse mínimo espaço para atuar deu origem a outras argumentações, estas acerca da necessidade de uma flexibilidade cambial maior. A tendência para uma flexibilidade maior foi associada a um comércio mais aberto, orientado para o exterior, e políticas de investimento em todo o mundo em desenvolvimento, assim como a altos níveis de mobilidade de capital internacional nos anos 90. É incontestável o sucesso da estratégia da Argentina em reduzir a inflação e restabelecer a estabilidade macroeconômica diante do aumento de volatilidade internacional. No entanto é difícil ignorar os trade-offs: a valorização real constante do peso, a perda da competitividade comercial e o aumento dos déficits em conta corrente, tudo isso contribuiu para níveis de desemprego de dois dígitos, sem precedentes na Argentina. Por causa desses trade-offs, defensores de regimes mais flexíveis insistem em que é menos oneroso seguir ajustes da balança de pagamentos pelo atrelamento a um mecanismo cambial flexível. Sob um regime mais flexível, os custos de uma política insustentável podem se tornar de imediato aparentes através de movimentos nas taxas de câmbio reais e nos preços. Por conseguinte, um regime flexível pode exercer uma disciplina também forte sobre a política. ${ }^{5}$

Os debates sobre taxas de câmbio fixas versus taxas flexíveis tornaram-se mais nebulosos pelo fato de que nenhuma delas se sobrepõe à outra em termos de desempenho macroeconômico nos anos 90 . Durante o período que se seguiu à crise da dívida de 1982, a inflação pareceu continuamente mais baixa e menos volátil em países com taxas fixas, mas essa diferença diminuiu ao longo da última década. ${ }^{6}$

\footnotetext{
${ }^{4}$ Uma discussão completa dos prós e contras das currency boards pode ser encontrada em Steve Hanke e Kurt Shuler, "Currency Boards and Currency Convertibility", Cato Journal. vol. 12 (1993), pp. 687705; John Williamson, What Role for Currency Boards? (Institute for International Economics, 1995); e Richard J. Sweeney, "Exchange Rate Crises: Are Currency Boards the Answer for Emerging Market Economies?”, in Sweeney, Wihlbor, and Willett, orgs., Exchange Rate Policies, pp. 265-94.

${ }^{5}$ Caramazza e Aziz, Fixed or Flexible? p. 7.

${ }^{6}$ Ibid, p. 5.
} 
Desse modo, a mudança notável para uma flexibilidade maior parece resultar do fato de que as considerações que afetam a escolha de um regime cambial tendem a mudar ao longo do tempo. Como mostram os capítulos escritos por Timothy Kessler e Eliana Cardoso neste volume, quando o México e o Brasil estavam sofrendo uma alta inflação, as autoridades perceberam sabiamente que as taxas fixas eram o segredo para um esforço de estabilização bem-sucedida. Quando essa missão foi cumprida, porém, apareceram outras objeções. Os desequilíbrios externos se avolumaram sob as pressões de valorização da moeda e o surgimento de entradas de capital, deixando pouca escolha aos dois países, a não ser a de optar por taxas flutuantes que permitiam mais flexibilidade no ajuste de desequilíbrios externos.

É interessante notar que, desde a crise do peso mexicano, cm 1994, a Argentina esteve várias vezes à beira do mesmo precipício da valorização da moeda e da volatilidade externa que impeliram o México a abandonar a taxa de câmbio fixa. E agora, na esteira da desvalorização do Brasil, em janeiro de 1999, a Argentina se encontra em outra proeminência econômica. No entanto, embora as condições que num primeiro momento levaram à adoção de uma taxa de câmbio rigidamente fixa tenham mudado muitíssimo, as autoridades argentinas declararam, mais uma vez, sua intenção de manter o currency board, em vez de mudar para uma estratégia mais flexível e potencialmente menos onerosa. O restante deste capítulo explora o por quê disso. Depois de rever brevemente o histórico positivo da reforma sob o Plano de Convertibilidade, assim como a capacidade das autoridades de defender o peso diante da volatilidade externa contínua, que se iniciou com o "choque tequila” de 1995, o capítulo se volta, então, a considerações mais longas com relação ao desenvolvimento da economia política argentina na era da convertibilidade.

\section{O APOGEU DO PLANO DE CONVERTIBILIDADE, 1991-1994}

Embora possa chocar a maior parte dos argentinos, a volta da hiperinflação ao país, durante 1989-1991, representou o auge de quase quarenta anos de má administração econômica, por parte do governo, e turbulências políticas. ${ }^{7}$ Em comparação com os períodos prolongados de alto crescimento e estabilidade cambial testemunhados durante os anos de "milagre" no Brasil, que se iniciaram nos anos 60, ou a expansão animadora pós-guerra do México, sob um modelo de "desenvolvimento estabilizado", a Argentina continuou sendo diferente. Apesar da sua condição de terceira maior economia na região, entre 1950 e 1991 o baixo índice de crescimento, a inflação alta e os déficits fiscais crônicos afligiram sem cessar o

\footnotetext{
${ }^{7}$ Os argumentos nesta seção são emprestados daqueles desenvolvidos por Manuel Pastor e Carol Wise em dois artigos: "Stabilization and its Discontents: Argentina's Economic Restructuring in the 1990's", World Development, vol. 27 (1999), pp. 477-503; “The Politics of Second-Generation Reform”, Journal of Democracy, vol. 10 (1999), pp. 34-48.
} 
país. ${ }^{8}$ Eleito no programa do partido peronista, em 1989, o governo de Menem lutou durante quase dois anos, sem sucesso, para reverter essas tendências que vinham de longa data. Quando, em 1989, a inflação anual se aproximou dos 5.000\% e as finanças públicas sofreram um colapso, os argentinos clamaram por alívio nas pesquisas de opinião pública. Enfim, ficou claro que a resolução de uma crise dessa grandeza iria requerer uma resposta igualmente dramática.

Como primeiro passo, Menem se distanciou das fortes influências intervencionistas que ainda prevaleciam em seu próprio partido peronista ou Partido Justicialista (PJ), e declarou abertamente sua adesão a um programa ambicioso de reforma de mercado. De forma semelhante a outros líderes políticos da região, que tinham sido evasivos com relação a suas preferências de reforma antes de sua eleição e depois foram mais pragmáticos quando se estabeleceram as realidades de estabilização macroeconômica, Menem surpreendeu seus próprios defensores que se encontravam nas categorias da mão-de-obra organizada e empresários voltados para o mercado interno, forjando um difícil programa de liberalização, privatização e desregulamentação. Da mesma forma que esses outros líderes - por exemplo, Carlos Andres Peres, da Venezuela, e Alberto Fujimori, do Peru - Menem foi de imediato pressionado a ampliar suas bases de coalizão, de forma a induzir de forma mais vigorosa os representantes do setor privado, orientados internacionalmente a aderirem ao programa de reforma. Daí a confiança inicial de Menem numa equipe de assessores técnicos associados à maior empresa transnacional do país, Bunge and Born Group, e, em seguida, a nomeação de Domingo Cavallo como ministro das Finanças, no início de 1991. Na qualidade de economista que impunha respeito tanto nos círculos financeiros nacionais quanto internacionais, Cavallo não só arquitetou o Plano de Convertibilidade, como também se tornou o único e mais importante garantidor aos olhos dos investidores estrangeiros.

O Plano de Convertibilidade de 1991, que fixou o peso argentino com relação ao dólar americano sob um currency board, emergiu como a peça central tanto do esforço de estabilização da equipe de Menem quanto de vários componentes políticos, num conjunto mais amplo de reformas estruturais baseadas no mercado. Duas leis-chave anteriores aprovadas pelo governo de Menem já tinham assinalado a seriedade do compromisso da Argentina com a reestruturação econômica pelas linhas de mercado: a Lei de Emergência Econômica e a Lei de Reforma Estatal, ambas aprovadas em 1989, foram para o centro do atoleiro fiscal em que se encontrava a Argentina desde o fim do primeiro governo de Juan Perón, em meados dos anos 50. A primeira suspendeu o complexo esquema de preferências e subsídios manufatureiros que tinham sido a base do protecionismo da Argentina e autorizou demissões justificadas pelo excesso de pessoal no setor público; a última lançou a base legal para a privatização em ampla escala das estatais tomadas pelas dívidas,

\footnotetext{
${ }^{8}$ I. M. D. Little, Richard N. Cooper, W. Max Corden, e Sarath Rajapatirana, Boom, Crisis, and Adjustment: The Macroeconomic Experience of Developing Countries (Nova York: Oxford University Press e Banco Central, 1993), pp. 185-92.
} 
incluindo companhias dos setores petroquímico, ferroviário, de navegação, de estradas de rodagem, telefonia e companhias aéreas. ${ }^{9}$

Graças à força do bloqueio peronista ao Congresso da Argentina, delegou-se ao Executivo o poder de legislar outras reformas nos impostos, no comércio e reformas reguladoras através de decretos do poder Executivo. ${ }^{10} \mathrm{O}$ sistema de impostos foi reelaborado em torno de um imposto de valor agregado e um imposto de renda crescente, foram eliminadas as isenções em larga escala e foram fortalecidos os mecanismos institucionais para observância e cobrança. No âmbito comercial, a Argentina seguiu uma estratégia em duas frentes: a liberalização unilateral das tarifas, com o forte apoio das instituições multilaterais no fim dos anos 80 , e a busca de outras reduções das barreiras comerciais através da participação no Mercado Comum do Cone Sul (Mercosul), lançado pela Argentina, Brasil, Paraguai e Uruguai no começo dos anos 90 . Em março de 1991, a tarifa média tinha sido reduzida para $10 \%$ ( $11 \%$ em insumos industriais e $22 \%$ em manufaturados). Mais tarde, nesse mesmo ano, essas medidas sobre o comércio e impostos foram seguidas por amplas reformas reguladoras. O mercado do petróleo e os regimes de investimento estrangeiro foram completamente liberados, e as restrições ficaram reduzidas em vários mercados internos (comunicações, transporte, agricultura e a Bolsa de Valores de Buenos Aires).

Simultaneamente, a equipe de Cavallo trabalhou para fortalecer a base financeira necessária para tornar viável o Plano de Convertibilidade. A equipe tinha ancorado a taxa de câmbio nominal ao dólar americano e tinha proibido toda e qualquer emissão de moeda não lastreada por sólidas reservas no Banco Central; a tarefa a seguir era acumular um nível de reservas internacionais producente para um aumento não inflacionário na liquidez e na atividade econômica. Embora as reservas internacionais do país fossem limitadas no início do plano, a dolarização em larga escala da economia argentina, sob um cenário de hiperinflação, tornou mais fácil a tarefa do governo de lastrear a base monetária interna no câmbio exterior. ${ }^{11}$ A redução das taxas de juros norte-americanas em 1991 facilitou o acúmulo maior de câmbio exterior, que impeliu os investidores a procurarem retornos sobre investimentos em mercados emergentes como o da Argentina. Esse desenvolvimento, combinado com a alienação agressiva do ativo estatal e a repatriação, há tanto tempo esperada, do capital especulativo do exterior, expandiu a base de reserva externa da Argentina de US\$ 2,4 bilhões, em março de 1991, para mais de US\$ 6 bilhões no final do ano. ${ }^{12}$

\footnotetext{
${ }^{9}$ Pablo Gerchunoff e Juan Carlos Torre, “La política de liberalización económica em la administración de Menem “, Desarrollo Económico, vol. 16 (outubro-dezembro de 1996 ), pp. 733-68.

${ }^{10}$ Fundación de Investigaciones Económicas Latinoamericanas (FIEL), “A Special Report on the Argentine Economy during 1991-1995”, Indicadores de Coyuntura, vol. 35 (outubro de 1995), pp. iii-xviii.

${ }^{11}$ Pamela K. Starr, "Government Coalitions and the Viability of Currency Boards: Argentina under the Cavallo Plan”, Journal of Interamerican Studies and World Affairs, vol. 39 (1997), pp. 83-133.

12 Todas as quantias são em dólares norte-americanos.
} 
Dada a série aparentemente interminável de malsucedidos planos de estabilização que o país tinha suportado até esse momento, até mesmo os arquitetos do currency board foram surpreendidos por seu sucesso num prazo tão curto. De 1991 a 1994, a economia argentina teve sua expansão mais importante e mais longa de todo o período pós-guerra. As taxas médias anuais de inflação foram reduzidas de 84\%, em 1991, para 3,9\% em 1994; durante esse mesmo período de tempo, o PIB cresceu a uma taxa anual média de $7,7 \%$, o consumo a uma taxa anual de $8,6 \%$ e o investimento real a um a taxa anual de $22 \% .{ }^{13}$ Sob o ímpeto de receitas maiores, geradas pela reforma radical do sistema de impostos elaborada por Cavallo, e com um impulso extra desse rápido desenvolvimento produzido pelo consumo, a balança inicial (sem incidência de juros) do governo federal mudou de um déficit de 10,5\% do PIB, em 1989, para um excedente em 1992 e 1993. ${ }^{14}$ Em 1994, essa combinação de estabilidade de preço, entradas de capital e expansão das reservas de câmbio exterior possibilitaram à equipe econômica reduzir as taxas de juros à metade. A seguir, o acesso mais fácil ao capital financiou uma expansão significativa do crescimento e investimento na Argentina, conforme mostra o quadro 5.1.

Foi o contexto de grave crise econômica que permitiu ao presidente Menem agir com mais audácia do que qualquer um de seus antecessores contemporâneos no âmbito da reforma, e foi o surpreendente sucesso dessa primeira fase de estabilização que possibilitou ao governo sedimentar uma forte coalizão de reforma, uma coalizão que não tinha semelhança alguma com os defensores populistas-nacionalistas, baseados na união, que tinham sido tão importantes na eleição de Menem no programa do partido peronista, em 1989. Mais tarde se tornaria evidente que foi pela demora em implementar as reformas de mercado, no nível do governo das províncias e na manutenção de "encraves iliberais", tais como o mercado de trabalho, fortemente regulado, que as reformas fundamentais (liberalização, privatização, convertibilidade) se tornaram viáveis do ponto de vista político. ${ }^{15}$ No entanto, ao atingir simultaneamente grandes grupos de interesses, classes médias, tecnocratas de espírito liberal e consumidores em geral, Menem ampliou suas bases de apoio de forma que pareceu ter cortado, de uma vez por todas, as asas mais tradicionais do peronismo. Como o Plano de Convertibilidade se tornou o ponto central para uma aliança política pró-estabilização mais centrista na Argentina, Menem agiu com facilidade no sentido do convite, em 1995, para sua reeleição. No entanto, o colapso financeiro inesperado do México em fins de 1994 mudou rapidamente o centro de gravidade econômico e político na Argentina: o currency

\footnotetext{
${ }^{13}$ FIEL, “Argentine Economy”, p. xv; e Gerchunoff e Torre, "La politica de liberalización económica”, p.129

${ }^{14}$ Little, Cooper, Corden e Rajapatirana, Boom, Crisis, and Adjustment, p. 194.

${ }^{15}$ Ver Javier Corrales, “ Presidents, Ruling Parties, and Party Rules: A Theory on the Politics of Economic Reform in Latin America”, Comparative Politics, vol. 32 (2000), pp. 127-50; e Juliana Bambaci,, Tamara Saront, e Mariano Tommasi, “The Political Economy of Economic Reforms in Argentina”, Centro de Estudios para el Desarrollo Institucional (CEDI), Buenos Aires, janeiro de 2000.
} 
board, $e$ os esforços de Menem e de seus assessores econômicos para salvá-lo foram logo colocados em teste extremo.

\section{DEFESA DO CURRENCY BOARD, 1995-1999}

Mesmo antes de a Argentina ser contagiada pela crise do peso mexicano, ou "choque tequila", o Plano de Convertibilidade e o amplo programa de reformas que o estruturava tinham começado a mostrar algumas tensões. Apesar do ritmo impressionante da estabilização econômica, a inflação na Argentina ainda estava mais alta do que nos Estados Unidos durante o período de 1991-1994. O resultado disso, conforme evidenciado no quadro 5.1, foi uma constante valorização real do peso, que se refletiu de imediato nos números do déficit comercial de 1992.

O cenário fiscal também estava perturbado, já que as receitas públicas derivavam desproporcionalmente do imposto mais regressivo do valor agregado. As receitas com impostos tinham aumentado pronunciadamente por causa do rápido desenvolvimento do consumo, mas os gastos públicos também continuaram altos. As baixas taxas de poupança (públicas e privadas) durante esse período sugeriam que nem o governo nem os consumidores argentinos tinham abandonado suas tendências pró-cíclicas de gastar em demasia quando a economia ia bem. Talvez a maior surpresa tenha sido a taxa de desemprego, que subiu de 7\%, em 1990, para $12 \%$, em 1994. Com certeza, algumas dessas perdas de emprego tinham sido previstas no contexto da tendência de privatização, mas também se esperava - pelo menos aos olhos dos observadores externos - que essas perdas fossem superadas pela liberalização dos mercados de trabalho fortemente regulados da Argentina. $\mathrm{O}$ fato de o governo de Menem, ao longo de toda uma década, nunca ter perseguido esse objetivo com muita convicção reflete a forma como o Executivo ainda estava arraigado a suas antigas raízes no partido peronista.

\section{O Choque Tequila de 1995}

No início de 1995, tornou-se aparente o lado negativo do Plano de Convertibilidade. Enquanto os fatores externos fortuitos de 1991 a 1994 - incluindo as baixas taxas de juros e os altos níveis de liquidez internacional - tinham ajudado a incrementar a recuperação da Argentina, a inversão dessas tendências, em fins de 1994, interrompeu abruptamente a expansão econômica. Os temores dos investidores sobre a possível inadimplência do México com relação a sua maciça dívida de curto prazo tinham provocado não somente uma corrida ao peso mexicano, mas também uma rápida fuga de capitais do México e de outros mercados emergentes em dificuldades semelhantes - isto é, os mercados que demonstravam supervalorização real da taxa de câmbio, que produziam déficits em conta corrente e aumentavam as obrigações da dívida. A rapidez e a força com que esses choques estrangeiros foram transmitidos para a economia da Argentina deveriam ter sido esperadas, dada a confiança intencional do Plano de Convertibilidade nos ajustes 


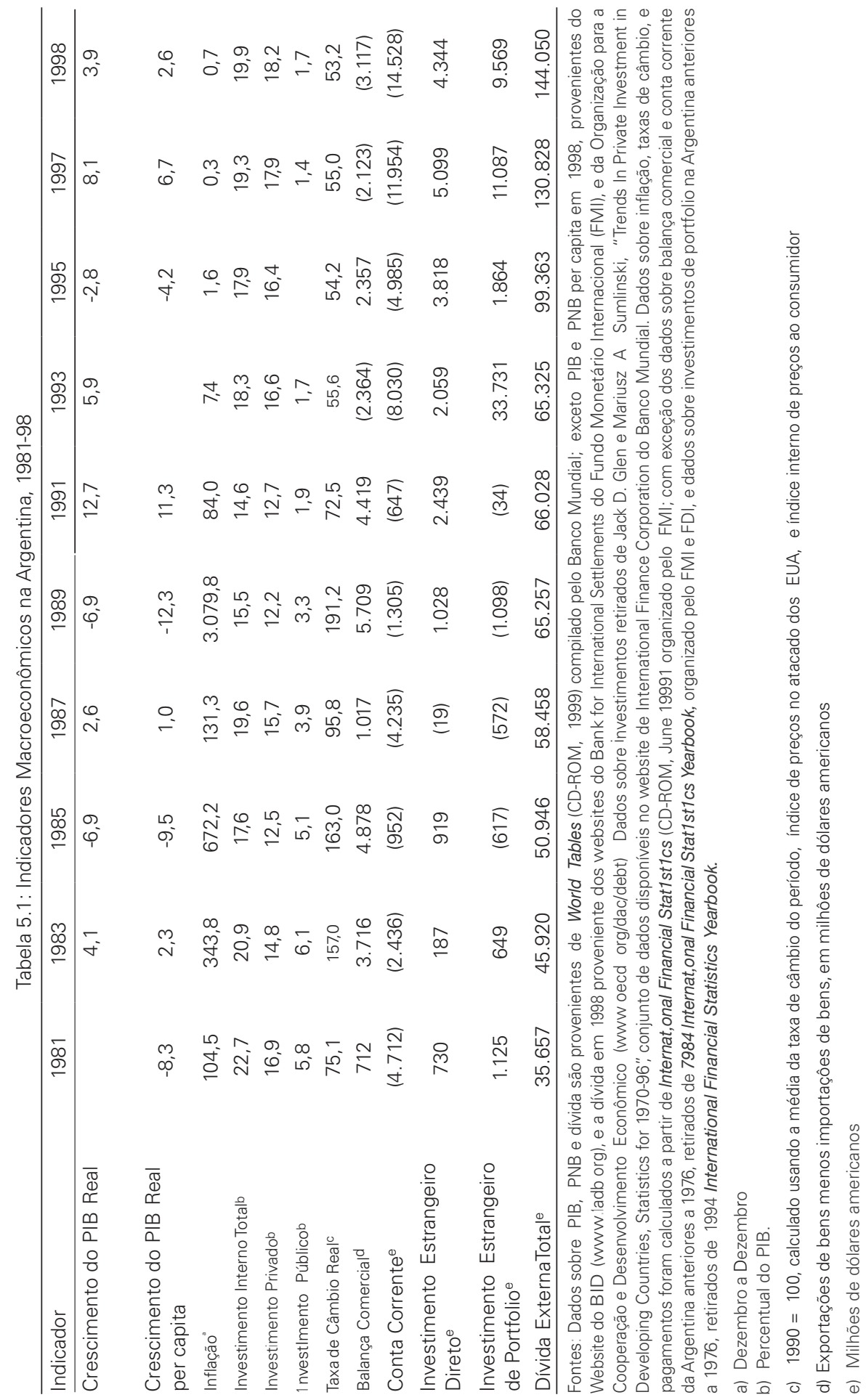


externos "automáticos". No entanto, no início de 1995, quando os depósitos bancários caíram 17 \% e US\$ 5,5 bilhões saíram do país, as autoridades se viram em disputa para defender o currency board. As perdas totais durante o ano de 1995 chegaram a 4,6\% do PIB, incluindo uma contração de $6,4 \%$ na produção industrial. E, como mostra o quadro 5.1, a dívida externa total tinha aumentado um terço entre 1991 e 1995, o que indicava até que ponto a alta rentabilidade do Plano de Convertibilidade sobre o crescimento dependia de empréstimos externos.

As opções de ajuste disponíveis sob o currency board eram limitadas, mas no final eram eficazes em tranquilizar os investidores acerca do compromisso da $\mathrm{Ar}$ gentina com um modelo econômico liberal baseado numa taxa de câmbio fixa. A curto prazo, as taxas de juros foram rapidamente elevadas para interromper a saída de capital, e o governo foi forçado a cortar mais de US\$ 1 bilhão do orçamento nacional somente em 1995. Quando a intensidade da crise começou a diminuir, a equipe de Menem teve que enfrentar três importantes questões de reforma que as restrições inerentes ao Plano de Convertibilidade tornaram urgentes. Primeiro, tendo privado o Banco Central de seu papel de emprestador de última instância, as autoridades não podiam mais ignorar as debilidades e a desordem ainda presentes no sistema bancário nacional. Desse modo, o ano de 1995 marcou o início de uma profunda reestruturação do setor bancário, de modo que, um ano depois, os depósitos excediam seus níveis no sistema financeiro antes do choque tequila. Em oposição ao México, onde uma crise bancária total exacerbou esforços de ajuste posteriores, desde 1994 a determinação da Argentina de agir agressivamente nessa frente propiciou uma proteção crucial contra choques financeiros futuros.

No âmbito fiscal, o aumento das cobranças de impostos, o corte de gastos e a renovação do sistema de seguro social foram os primeiros passos claramente necessários para a racionalização da política fiscal, mas só isso não bastava. $\mathrm{Na}$ esteira do choque tequila, tornou-se óbvio que teoricamente nenhum progresso tinha sido feiro na reforma de política fiscal no âmbito das províncias. Além disso, o contraste prolongado entre a decisão fiscal em nível federal e a frouxidão total nos governos provinciais tinha periodicamente reduzido o ritmo da Argentina em suas tentativas de cumprir as metas fiscais acordadas com o Fundo Monetário Internacional (FMI). Na verdade, os gastos públicos provinciais antes da crise de 1995 tinham de fato aumentado mais de $13 \%$ ao ano - um outro sinal de que Menem não tinha abandonado por completo as velhas táticas patrimoniais do peronismo. Essa demora na otimização dos orçamentos provinciais e na privatização de várias entidades regionais mantidas pelo Estado explica a popularidade continuada de Menem nas regiões, depois que sua boa acolhida se tinha desgastado claramente entre os eleitores em Buenos Aires. Isso também revela a ira aparentemente repentina com que os constituintes provinciais se voltaram contra o governo federal quando o ajuste fiscal finalmente atingiu as regiões, em 1995.

Restava ainda um desafio, que residia no ajuste de preços relativos, quando o currency board excluiu a desvalorização cambial real como uma opção viável. Diante, inicialmente, da competitividade em declínio da taxa de câmbio e da pressão dos exportadores para reverter essa tendência, o governo procurou atacar o 
déficit comercial crescente através de uma combinação de tarifas mais elevadas e subsídios para exportação. Ao mesmo tempo, a equipe econômica procurou compensar a valorização real do peso, estimulando ganhos rápidos em produtividade. Embora os números de produtividade da mão-de-obra se tivessem expandido em 4,1\%, em média, de 1991 a 1995, a taxa de desemprego também cresceu. Com essa taxa de desemprego atingindo seu pico em $20 \%$ no ano de 1995 , os ganhos com produtividade obviamente ainda dependiam muito da dispensa de funcionários e da redução das empresas, enquanto a eficiência continuava em atraso. Por acaso, sob o impulso de preços crescentes das commodities e da nova demanda de produtos argentinos no Brasil, quando o Plano Real deu o pontapé inicial, a balança comercial de 1995 teve um excedente. Não importava se o problema do preço relativo continuava - a equipe econômica se considerava responsável pela rápida reviravolta no crescimento e investimento, conforme mostra o quadro 5.1, e pelo pacote de empréstimos de US\$ 8,4 bilhões concedido à Argentina pelas instituições multilaterais em 1995.

Em meados de 1996, a confiança de Menem no Plano de Convertibilidade era tal que ele acabou demitindo Cavallo, pondo um fim aos cinco anos de uma rivalidade pública diária absurda e cáustica entre os dois homens. Depois de uma certa flutuação inicial, os mercados se mantiveram, apesar dessas notícias, quando Menem substituiu Cavallo por Roque Fernández, um ex-membro da diretoria do Banco Central e defensor da reforma da convertibilidade e da reforma econômica liberal. Nesse momento, o Plano de Convertibilidade cruzou um importante limiar: sua credibilidade não mais dependia da reputação e do prestígio de um único funcionário do governo, mas do histórico positivo da reforma. Com a taxa de crescimento de 1997 atingindo 8,4\%, pareceu que o choque tequila tinha sido uma ruptura temporária a partir da qual a economia reestruturada da Argentina tinha emergido ainda mais forte. Como se sabe, no entanto, embora a Argentina tivesse claramente escapado da síndrome desafortunada do "corta-relaxa-quebra" que Javier Corrales atribui ao caso da Venezuela (ver capítulo 6), o país tinha conseguido voltar ao seu ponto de equilíbrio exatamente na hora de uma nova rodada de choques externos.

\section{Excessos da Ásia, inadimplência da Rússia e desvalorização do Brasil}

Numa sucessão bem rápida, as autoridades foram confrontadas com uma série de desvalorizações desestabilizadoras das moedas que começaram em meados de 1997 por toda a Ásia; por contágio financeiro da desvalorização da Rússia e inadimplência da dívida em 1998 e pela desvalorização de 40\% da moeda brasileira no início de 1999. Embora o impacto do contágio da Ásia e a unificação da Rússia tenham prejudicado definitivamente a Argentina, os números no quadro 5.2 mostram que a força desses choques não se assemelhou ao dano sofrido em virtude da desvalorização mexicana. Os principais efeitos colaterais desses choques posteriores foram o aumento das taxas de juros reais e um aumento súbito nos preços dos bens, mas dessa vez os capitais nacionais e estrangeiros não saíram do 
país. A resistência da economia argentina a uma outra crise financeira total pode ser atribuída ao progresso da reforma do setor bancário e fiscal em consequência do choque tequila, reforma essa estimulada pela participação maior dos bancos estrangeiros no sistema financeiro do país.

Em 1998, o déficit fiscal da Argentina era baixo em relação aos padrões da América Latina (1,3\% do PIB), e a dívida de curto prazo parecia administrável em $3 \%$ das responsabilidades totais do setor público. A dívida externa total do país estava muito alta, em $50 \%$ do PIB, embora um desempenho bom, de modo geral, ainda facilitasse muito a obtenção de empréstimos no exterior por parte da Argentina. Além disso, e em forte contraste com o México, a Argentina tinha desenvolvido uma estrutura para supervisão dos bancos e tinha consolidado seu sistema bancário de um modo tal que o seu setor financeiro estava entre os mais sofisticados da região. ${ }^{16}$ Embora o crescimento conjunto tenha caído para cerca de 4,2\% do PIB em 1998 e o desemprego tenha continuado numa faixa de $13 \%$ a $14 \%$, a capacidade do país de resistir a esses choques sustentou ainda mais a credibilidade do currency board. De fato, como a Argentina estava a se tornar o primeiro país de mercado emergente a se voltar para os mercados de capital internacional depois das quedas da Ásia e Rússia, o currency board se tornou uma fixação na mente dos eleitores, políticos e autoridades. Se não era um regime perfeito, a convertibilidade certamente se tinha tornado o predileto.

Tabela 5.2: Impactos dos Choques sobre a Economia Argentina durante a Época de Convertibilidade

\begin{tabular}{lcccc}
\hline \multicolumn{1}{c}{ Indicador } & $\begin{array}{c}\text { Desvalorização } \\
\text { Mexicana }\end{array}$ & $\begin{array}{c}\text { Renúncia de } \\
\text { Cavallo }\end{array}$ & $\begin{array}{c}\text { Excessos } \\
\text { na Ásia }\end{array}$ & $\begin{array}{c}\text { Inadimplência } \\
\text { Russa }\end{array}$ \\
\hline $\begin{array}{l}\text { Variáveis Monetárias } \\
\text { Variação no Portfólio } \\
\quad \text { pontos percentuais ) }\end{array}$ & 7,1 & 2.7 & 2,9 & 3,3 \\
$\quad \begin{array}{l}\text { Perda de Reserva (percentual) } \\
\text { Depósitos Totais (percentual) }\end{array}$ & $-35,6$ & $-9,8$ & $-4,9$ & -5.4 \\
Ativos Fmanceiros & -20.4 & $-1,6$ & 3,3 & 1,8 \\
$\quad$ Equity (percentual) & $-45,7$ & $-18,2$ & $-33,2$ & $-37,6$ \\
Dívida Externa & 1.623 & 156 & 405 & 884 \\
Risco de Moeda & 1244 & 207 & 308 & 279 \\
\hline
\end{tabular}

Fonte: "Data Watch Argentina", Global Data Watch (Morgan Guaranty Trust) 15 de Janeiro, 19999, p. 21.

a) Aumento na dolarização certificados de depósito em dólare s como porcentagem do tota I de certificados de depósito

b) Spread peso-dólar, certificados de depósito com vencimento em trinta dias

\footnotetext{
${ }^{16}$ Unidade de Inteligência Econômica, "Argentina”, Country Report, 4º. Trim. de 1998 (Londres), p. 8; e Charles Calomiris, “A Welcome to Foreign Banks Could Energize Mexico”, Wal1 Street Journal, 16 de julho de 1999, p. A 15.
} 
Depois da desvalorização brasileira de janeiro de 1999, começaram a surgir rumores de uma possível mudança para uma flexibilidade maior na taxa de câmbio em Buenos Aires. Essas reivindicações, combinadas com um aumento de especulação sobre altas súbitas da taxa de juros nos Estados Unidos, levaram o mercado acionário a uma verdadeira confusão. O governo de Menem rapidamente negou os rumores, declarando que iria voltar-se para a dolarização total da economia se os mercados perdessem a confiança no peso, e não abandonar o currency board. A resposta das autoridades norte-americanas sobre a proposta de dolarização foi polida, mas não especialmente incentivadora. (Devido à falta de fortes ligações comerciais e de investimento entre a Argentina e os Estados Unidos, os candidatos mais prováveis para uma área de moeda dolarizada seriam os Estados Unidos, o Canadá e o México, e mesmo assim essa seria a possibilidade de um futuro bem distante. $)^{17}$

A necessidade de uma credibilidade renovada do currency board durante o choque brasileiro derivou primeiramente do aumento das margens de lucro peso dólar nas taxas de juros dos empréstimos em 1999 e, em segundo lugar, do impacto altamente adverso que se atribuiu à desvalorização brasileira sobre a economia real (ver tabela 5.3). Em oposição às crises do México, Ásia e Rússia, que tinham sido transmitidas para a economia argentina através do sistema financeiro, o principal veículo de transmissão no caso do choque brasileiro foi a economia real. Enquanto a expansão das exportações da Argentina para o mercado brasileiro (atribuíveis à valorização do real brasileiro contra o peso) tinha sido importante para a economia da Argentina - e daí a recuperação da crise de 1995 -, agora a balança comercial bilateral era impulsionada na direção oposta.

Tabela 5.3: Previsões para a Argentina Depois da Desvalorização no Brasil

Em \%, exceto quando indicado

\begin{tabular}{lcc}
\hline Indicador & 1998 & 1999 \\
\hline PIB real & 4,3 & 3,2 \\
Consumo real e estoques & 4,1 & 1,6 \\
Investimentos fixos & 7,2 & 8,0 \\
Exportação real de bens e serviços & 7,0 & 5,0 \\
Importação real de bens e serviços & 8,5 & 7,0 \\
Preços ao consumidor & 0,9 & 1,0 \\
Balanço conta corrente (US\$ bilhões) & 12,5 & 12,1 \\
Porcentagem do PIB & 3.7 & 3.7 \\
Balança comercial de bens (US\$ bilhõe s ) & 6,0 & 5,3 \\
Balanço do Governo (US\$ bilhões) & 3,9 & 5.4 \\
\hline
\end{tabular}

Fonte: "Data Watch Argentina”, Global Data Watch (Morgan Guaranty Trust\}, 29 de janeiro de 1999, p. 19.

${ }^{17}$ J. P. Morgan, “Monetary Union in the Americas”, Economic Research Note (12 de fevereiro de 1999). 
Em fins de 1998, o Brasil era responsável por 23\% das importações da Argentina e $30,5 \%$ de suas exportações. Como a desvalorização do real empurrou a taxa cambial bilateral do peso para quase $18 \%$ em termos reais, o peso do ajuste rapidamente caiu sobre o setor comerciável da Argentina. Essa mudança desfavorável em preços relativos foi exacerbada durante todo o ano de 1999 pela valorização do dólar americano, ao qual está ancorado o currency board. Com a produção industrial caindo a 9,5\% nos três primeiros trimestres de 1999, e com o crescimento do desequilíbrio nos números de comércio e conta corrente, tornou-se evidente que o ajuste monetário e fiscal usual, que tinha servido tão bem ao Plano de Convertibilidade no passado, não seria suficiente para reverter essas tendências negativas. Conseguiu-se certo alívio através do prazo acordado com o FMI para um relaxamento nas metas fiscais de 1999-2000 da Argentina, quando uma recessão profunda novamente conduziu a cobrança de impostos a níveis inferiores aos projetados. As projeções fiscais anteriores também se tornaram irreais pela iminência das eleições presidenciais (outubro de 1999), um período nada propício para restringir os gastos do governo e certamente não no contexto de uma outra crise econômica.

A desvalorização brasileira produziu o mesmo dilema que havia sido escondido embaixo do tapete pela equipe de Menem no meio do ponto de inversão econômica de 1996: como os preços relativos podem ser ajustados sob um regime cambial fixo que impeça a desvalorização? A resposta óbvia é seguir um ajuste cambial real através de ganhos rápidos com produtividade que possam impulsionar a competitividade do país. O Congresso argentino, no entanto, não tinha conseguido aprovar nem mesmo os requisitos mais básicos para que se pudessem alcançar esses objetivos, tais como custos mais baixos da mão-de-obra e de impostos para o empresariado. Como era de se prever, essa ausência de incentivos concretos para estimular a produtividade, por parte do governo, associada ao grande fluxo de produtos brasileiros no mercado interno, deram origem a novas demandas de protecionismo por parte do setor privado na Argentina. ${ }^{18}$ Ao mesmo tempo, sem abandonar sua adesão ao Plano de Convertibilidade, os grupos do setor privado se tornaram mais enfáticos em suas reivindicações por políticas competitivas para complementar melhor o currency board. No topo da lista estavam as demandas de redução das taxas de juros para capital de giro, uma redução no imposto de $35 \%$, sobre lucros, taxas mais baratas sobre fretes e serviços, e regulamentos trabalhistas mais flexíveis para reduzir o grande "custo Argentina" para fazer negócios. ${ }^{19}$

\footnotetext{
${ }^{18}$ Clifford Kraus, “Argentines Suffering from Brazil Crisis”, New York Times, 8 de fevereiro de 1999, p. A8.

${ }^{19}$ Focus on Big Financial Challenge", Latin American Weekly Report, 30 de novembro de 1990, pp.42-w.
} 


\section{A TRANSFORMAÇÃO DA ECONOMIA ARGENTINA SOB TAXA CAMBIAL FIXA}

As diferenças entre a economia política no período pré-reforma e na Argentina de hoje são tão vastas que um provável investidor que retornasse após uma ausência de dez anos teria muita dificuldade para entendê-las. Com relação a isso, têm sido notáveis os resultados do vasto programa de reformas de mercado da Argentina. Em todos os setores foram reduzidas as barreiras à competição e a economia da Argentina é agora um cenário consideravelmente mais estável, transparente e previsível para fazer negócios. No entanto, após quase uma década de esforços de reforma de mercado, os resultados a longo prazo ainda estão confusos. As principais dificuldades que a Argentina está enfrentando agora são (1) taxas de desemprego continuamente altas e uma piora na distribuição de renda; (2) problemas pendentes que rondam a competição, regulamentação e a fiscalização dos mercados internos; e (3) a falta de uma estratégia de desenvolvimento definida claramente, que reflita mais do que a estabilização de curto prazo e os imperativos de ajuste que dominaram a elaboração de políticas econômicas desde o lançamento do Plano de Convertibilidade. No meio da recessão de 1999, por exemplo, a ausência de uma estratégia concreta para a reativação econômica exacerbou os problemas - tais como o estabelecimento do índice recorde de $60 \%$ do serviço da dívida - que até então pareciam sob controle.

Voltando ao primeiro ponto, o quadro 5.4 demonstra até que ponto a capacidade do governo de Menem de estabilizar os preços e desencadear um padrão constante de crescimento e investimento não conseguiu inserir-se no cotidiano dos trabalhadores. Os níveis comparativamente altos de desemprego na Argentina nos anos 90 refletem o impacto cumulativo da privatização, das regras antiquadas do mercado de trabalho e o efeito deletério das distorções dos preços relativos. Como as estatais tradicionalmente eram responsáveis por apenas 3\% a $4 \%$ do emprego total do país, a privatização talvez seja menos preocupante do que outras causas de desemprego. Uma explicação mais convincente para o problema é a dos altos custos trabalhistas não salariais e várias restrições na contratação e demissão que prevaleceram durante o mandato de Menem, com dez anos de duração. Teoricamente, a introdução de uma flexibilidade maior no mercado de trabalho deveria acelerar os ajustes setoriais, permitir uma alocação mais eficiente de recursos, aliviar a pressão sobre a taxa de câmbio e desencadear uma expansão maior do emprego. ${ }^{20}$ Mas infelizmente não foi esse o caminho escolhido. Em vez disso, a valorização do

\footnotetext{
${ }^{20}$ Carolina Pessino, "The Labor Market during the Transition in Argentina”, in Sebastian Edwards e Nora Lustig, orgs., Labor Market Reform in Latin America (Brookings, 1997), pp. 151-200. Outros defenderam a ideia de que devido ao lento progresso na reforma de mercados de trabalho e ao efeito deletério cumulativo que uma taxa de câmbio não competitiva teve em perpetuar altas taxas de desemprego, a elaboração de códigos trabalhistas mais flexíveis dará pouco resultado se os preços relativos continuarem distorcidos. Ver Alejandro B. Rofman, Convertibilidad y desocupación en la Argentina de los'90 (Universidade de Buenos Aires, 1997).
} 
peso desde 1991 canalizou os recursos econômicos para atividades com capital mais intensivo no setor non-tradable, em que os ganhos com eficiência têm sido desiguais e os mercados de trabalho continuam distorcidos e deprimidos.

Como mostra o quadro 5.4, a tendência para a piora da distribuição da receita na Argentina corresponde a um padrão de toda a região nos anos 90. No entanto, as maiores perdas de receita sofridas pelos $40 \%$ da população mais pobre da Argentina foram exacerbadas pelo cenário desfavorável que acaba de ser descrito. Em termos regionais, a deterioração nos excedentes de receita está relacionada, primeiramente, a uma grande distância entre educação e diferenciais de habilidade e, em segundo lugar, ao aumento nos níveis de concentração de ativos desde o início da liberalização. ${ }^{21}$ Numa primeira avaliação, embora a população da Argentina ainda esteja entre as de nível mais elevado de educação na região, um legado significativo dos anos 80 é a deterioração da qualidade de treinamento, do acesso a este e das oportunidades educacionais. Esse declínio foi composto pela presença maior de empresas estrangeiras na economia argentina nos anos 90, sobretudo nos setores de serviços, e a propensão de esses investidores transferir em tecnologia e práticas de produção modernas que iam além das habilidades do trabalhador médio argentino. Desse modo, num primeiro momento a probabilidade de tornar-se parte dos $40 \%$ mais pobres da população trabalhadora é significativamente mais elevada.

A maior concentração de ativos produtivos na Argentina pós-privatização contribuiu ainda mais para esse aumento da heterogeneidade estrutural. Em princípio, as estatais foram vendidas sob as diretrizes da legislação formal antitruste; no entanto, uma visão retrospectiva mostra que a vontade política do governo de Menem de combater as práticas empresariais monopolistas foi nula. Quando a poeira assentou nas privatizações realizadas de 1991 a 1994, 66\% dessas empresas que tinham sido privatizadas de repente apareceram na lista das duzentas empresas mais importantes da Argentina. ${ }^{22}$ Além disso, cinquenta empresas nesse grupo recém privatizado rapidamente passaram a ser responsáveis por $60 \%$ dos lucros totais gerados pelas duzentas maiores. Em 1995, apenas três dessas empresas privatizadas eram responsáveis por $40 \%$ do giro total das setenta empresas listadas na Bolsa de Valores de Buenos Aires. ${ }^{23} \mathrm{~A}$ concentração de ativos dessa magnitude não é um bom presságio para as empresas pequenas e médias no setor produtivo, que não têm capital nem know-how para competir de maneira eficaz. Representa um presságio ainda pior para o trabalhador argentino, porque são essas menores empresas que sempre deram o impulso principal para a criação do emprego.

\footnotetext{
${ }^{21}$ Nancy Birdsall e Juan Luis Londono, "Asset Inequality Matters”, American Economic Review, vol. 87 (1997), pp. 32-8.

${ }^{22}$ Daniel Azpiazu, La concentración em la industria argentina a mediados de los años noventa (Buenos Aires: FLACSO, 1998 ).

${ }^{23}$ Argentina's Drift toward Concentration”, Latin American Weekly Report, 5, de outubro de 1995.
} 
Tabela 5.4: Crescimento, Investimento e Retorno Distributivo na Argentina, Brasil, Chile, e México, Anos Selecionados, 1986-1999

\begin{tabular}{lccccc}
\hline \multicolumn{1}{c}{ Indicador } & Período & Argentina & Brasil & Chile & México \\
\hline Crescimento PIB & $1990-99$ & 4,2 & 2,5 & 5,8 & 3,4 \\
Investimento Interno Bruto /PIB & $1990-98$ & 17,7 & 20,8 & 25,3 & 22,9 \\
Exportações/PIBa & $1990-98$ & 8,9 & 8,6 & 29,9 & 23,0 \\
$\begin{array}{l}\text { Variação percentual nos preços } \\
\text { ao consumidor em relação ao }\end{array}$ & Dez 1999 & $-1,8$ & 8,4 & 2,3 & 12,3 \\
ano anterior & & & & & \\
Salários Reaisb & $1990-99$ & 0,0 & 0,5 & 3,7 & 0,8 \\
Taxa de Emprego & $1990-98$ & 1,3 & 1,5 & 2,2 & 3,0 \\
Produiidade da Força de Trabalhob & $1990-95$ & 4,1 & $-0,1$ & 3,3 & $-2,2$ \\
Desemprego Urbanoc & $1990-98$ & 11,6 & 5.4 & 7,3 & 3,8 \\
Disparidade Educacionald & 1994 & $1,9(1$ & 1,3 & 1,5 & 3,1 \\
Percentual da renda nacional & 1986 & 16,2 & 9.7 & 12,6 & $12.7(1984)$ \\
acrescida aos: 40\% mais pobres & 1990 & 14,9 & 9,6 & 13,4 & 11,7 (1989) \\
& 1994 & 13,9 & 11,8 & 13,3 & 10,8 \\
& 1996 & 14,9 & 10,5 & 13,4 & 10,8 \\
& 1986 & 34,5 & 44,3 & 39,6 & $34,3(1984)$ \\
& 1990 & 34,8 & 41,7 & 39,2 & 39,0 (1989) \\
10\% mais ricos & 1994 & 34,2 & 42,5 & 40,3 & 41,2 \\
& 1996 & 35,8 & 44,3 & 39,4 & 42,8 \\
\hline
\end{tabular}

Fontes: dados sobre PIB retirados do website da Comissão Econômica para a América Latina e Caribe (CEPAl (www. ECLAC org). Dados sobre investimento interno bruto retirados de World Development Indicators (CD-ROM, 1998). Banco Mundial. Dados sobre exportações foram calculados a partir de dados sobre as respectivas contas nacionais retirados de International Financial Statistics (CD-ROM, setembro 1998), FMI, Dados sobre preços ao consumidor retirados de "Emerging Markets: Economic indicators", Morgan Guaranty Trust Company, Nova York. várias questões. Dados sobre salários reais retirados de Preliminary Overview of the Economy of Latin America and the Caribbean, 1997, CEPAL. Dados sobre taxa de emprego, produtividade da força de trabalho e desemprego urbano retirados de "Latin American Growth, Poverty, and Inequality", CEPAL News, vol. 7 (1997), n 27, pp 1-3, e ECLAC’s website. Dados sobre educação foram apresentados por Jere Behrman, Nancy Birdsall, e Miguel Székely em workshop sobre Mobilidade Social, Brookings Institution, Washington, D.C. 4-5 de Junho, 1998. Em relação à distribuição de renda nacional. dados chilenos e brasileiros foram baseados nas áreas urbanas e dados argentinos baseados em Buenos Aires, encontrados em The Equity Gap (1997). CEPAL. Dados mexicanos sobre renda monetária encontrados em Manuel Pastore e Carol Wise, "Mexican-Style Neoliberalism", In Carol Wise, org., The PostNAFTA Political Economy (Pennsylvania State University Press, 1998).
a) Exportações incluem bens e serviços
b) Taxa de crescimento médio anual
c) Taxa média anual
d) Atraso escolar em número médio de anos, de 15 a 18 anos.

Excetuando-se suas consequências adversas quanto à distribuição de receita, esse padrão perturbador de concentração empresarial também salienta um outro desafio enfrentado pela Argentina: deficiência contínua na implementação de regras acerca da competição, regulamentação e fiscalização dos mercados internos. Como o programa ambicioso da Argentina de reformas estruturais foi lançado simulta- 
neamente com o Plano de Convertibilidade e num espaço de tempo muito reduzido, as autoridades ainda têm alguns acertos a fazer nas áreas de regulamentação e fiscalização. Em alguns setores, tais como gás e eletricidade, os órgãos reguladores altamente profissionais defenderam de fato as regras relativas à qualidade e à competitividade do preço da prestação de serviço privado. Em outros setores, porém, tais como o das telecomunicações e água, as maiores empresas que operavam nesses mercados passaram a representar facilmente as comissões reguladoras.

Uma tendência mais perturbadora foram os diversos escândalos de corrupção que vieram à tona durante o governo Menem na década passada, muitos deles com origem no contexto do programa de privatização. Por exemplo, desde 1991 os preços dos serviços privatizados aumentaram $55 \%$ mais do que os dos outros produtos, uma tendência para a qual os representantes do governo ainda têm que dar alguma justificativa racional. ${ }^{24}$ Tendências como essas, combinadas com a identificação excessiva do governo Menem com grupos de interesse abastados com a indiferença aparente à taxa elevada de desemprego, além das pressões distributivas de renda, prejudicaram o apoio da opinião pública à reforma de mercado na $\mathrm{Ar}$ gentina. As pesquisas de opinião mais recentes mostram, por exemplo, que apenas $53 \%$ das pessoas entrevistadas consideram a reforma de mercado a melhor opção para o país, se comparados a $65 \%$ de apoio à reforma de mercado na América Latina como um todo. ${ }^{25} \mathrm{O}$ problema mais profundo, obviamente, foi a incapacidade da equipe de Menem de implementar os incentivos de mercado em áreas que oferecem os maiores ganhos com eficiência e receita (por exemplo, mercados de trabalho e política de competição), aderindo, ao mesmo tempo, a políticas monetárias e fiscais altamente ortodoxas, que atuam na direção oposta.

Enfim, a base das tendências macro e microeconômicas revistas neste capítulo é a ausência de uma estratégia coerente de desenvolvimento para dirigir a economia política a longo prazo. Por definição, o Plano de Convertibilidade e um conjunto mais amplo de reformas estruturais baseado na liberalização, privatização e desregulamentação sinalizam o compromisso da Argentina com uma estratégia de desenvolvimento orientada para o exterior. Essa estratégia tem muita afinidade com o pensamento corrente que sustenta que a forma mais rápida de melhorar um determinado nível de desenvolvimento do país é através da geração de atividades econômicas de valor agregado mais elevado dirigidas pelas exportações. ${ }^{26}$ Por exemplo, foi a abrangência explícita dessa abordagem, combinada com a adoção de um regime cambial descendentemente flexível, no início dos anos 80, a responsável pelo sucesso comparativo do Chile (ver quadro 5.4); de maneira semelhante, o México, pela promoção agressiva das exportações com valor agregado mais

\footnotetext{
24 “Argentina's Economy: Keeping the Reform Alive”, Economist, 23 de outubro de 1999, p.26.

${ }^{25}$ As pesquisas de opinião, baseadas em entrevistas ao vivo com 14.839 adultos em áreas urbanas na América Latina, foram realizadas por Latinobarómetro em dezembro de 1998 e janeiro de 1999.

${ }^{26}$ Sebastian Edwards, "Latin America's Underperformance”, Foreign Affairs, vol. 76 (março-abril de 1997), pp. 93-103.
} 
elevado, conjuntamente com uma taxa flutuante pós-1994, está seguindo, agora, os passos do Chile. Em ambos os casos, níveis elevados de comércio levaram ao crescimento e investimento econômicos baseados em atividades de valor agregado mais elevado. A Argentina não parece estar equilibrada para esse mesmo tipo de condição auto-sustentada. Embora o volume de comércio como percentual do PIB tenha dobrado desde 1990, a exportação de produtos agrícolas e de energia, de baixo valor agregado, bem como a importação de bens de capital e de bens duráveis de consumo dominaram a maior parte dessa expansão comercial. Até o momento, o comércio no Mercosul foi dominado por apenas dois parceiros (Argentina e Brasil) e um setor (automóveis), o que impede, no caso da Argentina, que o mesmo seja uma fonte de expansão mais dinâmica de emprego e de crescimento dirigido pelas exportações. Além disso, a desvalorização recente e o ajuste maciço do Brasil foram canalizados para essa grande debilidade: da noite para o dia, a produção automobilística argentina foi reduzida à metade. Para os policy makers argentinos, que continuam a excluir a desvalorização real da moeda como uma opção, a mensagem já foi dada; a tarefa a seguir é lançar rapidamente uma série de políticas competitivas que, no mínimo, reduziriam os custos empresariais, atingiriam exportações de valor agregado mais elevado para expansão e equipariam melhor os trabalhadores para competirem nos mercados de trabalho rapidamente mutáveis do país. $\mathrm{Na}$ ausência de uma estratégia mais agressiva nessa direção, os objetivos de ajustar os preços relativos e de estimular mais crescimento, emprego e ganhos com receita vão continuar frustrando as autoridades argentinas.

\section{DESENVOLVIMENTO POLÍTICO NA ERA DA CONVERTIBILIDADE}

Da mesma forma que o lançamento do Plano de Convertibilidade pôs um fim aos anos de caos econômico na Argentina, ele também deu uma oportunidade para que a política interna se estabilizasse. Em todo o período pós-guerra, as tendências econômicas tinham sido dirigidas sobremaneira por políticas internas que oscilavam erraticamente entre governos civis e militares. O advento do governo Menem marcou o fim de uma longa estagnação para a Argentina e o início de uma interação mais construtiva entre a política e a teoria econômica. A eleição de Menem em 1989 foi duplamente significativa no sentido de que, pela primeira vez, um presidente, eleito democraticamente, de um partido político na Argentina passou o bastão para um presidente eleito democraticamente de um outro partido. No entanto, quase imediatamente, as urgências da hiperinflação ameaçavam corroer todo e qualquer capital político que essa transição democrática pudesse ter produzido. Do ponto de vista político, a capacidade do país de transpor a série de obstáculos econômicos revistos neste capítulo pode ser dividida em três fases.

O desenvolvimento político durante o primeiro governo de Menem (19891995) focalizou apenas a estabilização econômica, a legislação e a implementação de reformas de mercado, bem como a formação de uma coalizão para apoiar essas políticas. De forma semelhante a outros realizadores de reformas de mercado nos 
anos 90, o governo atuou de forma autocrática, aprovando a maior parte das reformas através de uma série de decretos executivos (mais de 12 mil decretos tinham sido aprovados desde dezembro de 1993). Mas as próprias habilidades, comprovadas, de liderança do presidente também ajudaram a arregimentar uma coalizão que apoiou ativamente a estabilização macroeconômica e a sustentabilidade do Plano de Convertibilidade. Com relação a isso, Menem agiu magistralmente, convencendo aliados empresariais potenciais, aliados da classe média e da classe trabalhadora de seus ganhos futuros sob um modelo de mercado, enquanto apaziguava a oposição através de várias formas de compensação direta e indireta. ${ }^{27}$ Ao mesmo tempo, o presidente e sua coalizão foram bem-sucedidos em minimizar as perdas inevitáveis que iriam ocorrer no nível da economia real, tornando a política de reforma, por conseguinte, relativamente simples nesse estágio inicial: as medidas podem ter causado grandes distúrbios econômicos, mas os ganhos iniciais em termos de redução de inflação e retomada do crescimento não apenas foram notados como amplamente compartilhados.

Desse modo, pelo menos do ponto de vista da estabilização macroeconômica, a equipe de Menem tinha mobilizado o apoio suficiente para superar os dilemas de ação coletiva que tinham afligido o país por tanto tempo. No entanto, conforme se mencionou anteriormente, a oposição às reformas de mercado foi a seguir neutralizada de uma forma que rapidamente voltou para assombrar os policy makers, já que tanto a mão-de-obra organizada quanto os governos provinciais foram basicamente poupados, no mesmo grau, das medidas de liberalização e de corte de gastos que foram de pronto aplicadas à maior parte dos outros setores econômicos. Ao mesmo tempo que foram eficazes para manter o apoio de trabalhadores e eleitores regionais, o que foi crucial para as ambições de reeleição do presidente, o fato de a equipe de Menem ter amenizado as medidas de mercado nessas áreas rapidamente constituiu brechas (divergências) de reforma que teriam que ser transpostas para que o Plano de Convertibilidade fosse bem-sucedido. Enquanto o choque tequila de 1995 forçou um ajuste fiscal importante nas províncias, sob fortes pressões de financiadores multilaterais, a tarefa de aprovar um amplo pacote de reforma de mercado de trabalho foi finalmente deixada ao sucessor de Menem.

Desde a reintegração dos governos regionais, com o retorno do governo civil, em 1983, a Argentina teve classificação semelhante à do Brasil em sua alta porcentagem de transferências fiscais automáticas para as províncias e o amplo arbítrio

\footnotetext{
${ }^{27}$ Ver Sebastian Edwards e Daniel Lederman, "The Political Economy of Unilateral Trade Liberalization: The Case of Chile”, Working Paper 6510 (Cambridge, Mass.: National Bureau of Economic Research, abril de 1998), p. 62, tabela 5. De acordo com Edwards e Lederman, a compensação direta consiste de transferência de caixa ou valores mobiliários a grupos adversamente afetados por uma determinada reforma; a compensação indireta "implica a compensação de grupos afetados por uma reforma particular através do ajuste de uma política diferente que indiretamente aumenta suas receitas ou reduz seus custos de produção". Há fortes evidências de que a estratégia de reforma de Menem dependeu muito desses mecanismos compensatórios, conforme sugeriram Vicente Palermo e Marcos Novaro, Politica y poder en el gobierno de Menem (Buenos Aires: Grupo Editorial Norma, 1996).
} 
de gastos desfrutado por altos funcionários em nível subnacional. ${ }^{28}$ Esse acordo fiscal entre o governo central e as províncias também estava no âmago das relações entre Executivo e Legislativo na Argentina dos anos 90, quando as províncias controladas pelo partido peronista elegeram o Parlamento Alto (Câmara Alta) da legislatura e foram o instrumento da vitória presidencial de Menem, em 1989. Excetuando-se a demora nos cortes do Orçamento e na privatização dos bancos provinciais e outras entidades públicas, o governo Menem restituiu essa lealdade através da negociação de pactos fiscais em 1992 e 1993 que substituíram "os critérios de distribuição de receita previstos na lei de compartilhamento de renda bruta, de 1987 , com critérios que refletiam pouco além da celebração de acordos políticos". ${ }^{29} \mathrm{O}$ resultado foi um fluxo contínuo de transferências fiscais às províncias, quase sem restrições, $\mathrm{cm}$ oposição aos cortes exagerados no Orçamento executados nos centros urbanos do país. Mesmo depois de o corte ter caído sobre as finanças provinciais, após 1995, o bloco peronista no Congresso foi bem-sucedido em estender a natureza irrestrita de transferências fiscais provinciais ao segundo mandato de Menem, apesar das demandas da oposição por mais transparência e uma maior prestação de contas ao público.

$\mathrm{Na}$ frente trabalhista, embora o ambiente empresarial do país tenha sido muitíssimo transformado ao longo do período pós-guerra, a legislação trabalhista predominante datava do auge do populismo peronista, nos anos 50. Por exemplo, uma grande confederação trabalhista ainda predominava na negociação de regras e salários em indústrias, e, na hipótese de empresários e trabalhadores não chegarem a um acordo quanto a um novo contrato, a lei em vigor garantia que o contrato antigo prevaleceria automaticamente..$^{30}$ Ao mesmo tempo que essa receita era pouco adequada para os tipos de flexibilidade e inovação agora demandados pelo novo modelo de mercado, Menem e seus aliados congressistas evitaram o confronto direto com trabalhadores organizados sobre a desregulamentação do mercado de trabalho e outras reformas penosas do setor público. O resultado foi lealdade trabalhista nas pesquisas de opinião e uma grande redução no número de greves gerais e mobilizações sindicais durante o primeiro mandato de Menem, mas também uma série de reformas gradativas que não conseguiram reduzir a incerteza econômica ou os altos custos dos negócios na Argentina. Em 1995, o ministro do Trabalho admi-

\footnotetext{
${ }^{28}$ Este resumo dos laços políticos entre o governo central e as províncias foi tomado de Kathleen O’Neill, "Tugging at the Purse Strings: Fiscal Decentralization and State Discretion", documento apresentado no encontro anual da Associação de Estudos da América Latina, Miami, março de 2000, pp. 9-11.

${ }^{29}$ Kent Eaton, "Political Obstacles to Decentralization in Argentina and the Philippines", documento apresentado no encontro anual da Associação Norte-americana de Ciências Políticas (American Political Science Association), Boston, Mass., setembro de 1998, p. 7 (citado in O' Neill, “Tugging at the Purse Strings", p. 11).

${ }^{30}$ Clifford Krauss, "Injecting Change into Argentina”, New York Times, 8 de março de 2000, p. C1.
} 
tiu que tinham sido implementadas apenas $30 \%$ das medidas propostas para modernizar as relações entre empresários e trabalhadores na Argentina. ${ }^{31}$

Com o choque tequila, em 1995, e a reeleição de Menem logo depois, a política de reforma de mercado mudou para um outro plano. Na esteira da crise de 1995, o sucesso inicial do Plano de Convertibilidade na estabilização macroeconômica ficou do minado pela necessidade premente de melhorar a competitividade do país sob um regime cambial fixo e pelo aumento de pressão para o ajuste, visíveis nos números do quadro 5.4. Em pouco tempo, o temor da população de que o desemprego subisse vertiginosamente ultra passou seu temor de uma hiperinflação, com maior ênfase por parte dos policy makers em promover a eficiência e a produtividade, alimentando ainda mais essas inseguranças. Os ventos políticos se inverteram e a rede de alianças que formou a coalizão pró-estabilização durante o primeiro mandato de Menem recuou diante desses desafios de micro nível mais complicados. Uma nova coalizão de partidos de oposição se formou e começou a questionar a estratégia do governo da reforma de mercado com poucas redes de segurança. No entanto, os políticos da oposição já tinham criticado o currency board durante a campanha presidencial de 1995 e tinham sido penalizados por isso nas pesquisas de opinião. Desse modo, em vez de enfrentar cara a cara o Plano de Convertibilidade, eles começaram a trabalhar nos bastidores, retomando energicamente as causas do ajuste social, da corrupção e da reforma judicial.

Era uma plataforma que estava em consonância com os eleitores. O Partido Radical do centro venceu os peronistas nas primeiras eleições abertas para a prefeitura de Buenos Aires, em 1996, e, em 1997, uma coalizão ascendente entre os radicais e a coligação de centro-esquerda Frepaso conseguiu maioria no parlamento baixo da Câmara dos Depurados. Nesse momento, a mensagem foi dupla: os eleitores da Argentina estavam amedrontados com o choque tequila, mas ainda não estavam preparados para abandonar uma estratégia que tinha finalmente tirado o país da hiperinflação; porém os sacrifícios infligidos pelo ajuste de mercado também tinham invocado uma reação implacável do ponto de vista da distribuição de renda nas pesquisas de opinião, inclusive nas províncias, onde os peronistas tinham maioria nos governos de estado, mas perderam uma porcentagem crescente do voto popular. O legado do choque tequila foi tal que os perdedores no processo de reforma estavam agora relutantes em suportar o peso de outro ajuste, mesmo que ainda se tivesse que atacar uma longa lista de medidas desregulamentadoras e de incentivo à eficiência. Em comparação com o primeiro mandato de Menem, a política de reforma de mercado depois de 1995 não era nada simples, e as soluções no âmbito da distribuição tiveram que se tornar mais complexas.

Nessa conjuntura do processo de reforma, também ficou claro que um currency board que, numa área, restringe um governo com relação a políticas irresponsáveis poderia, em outra, atuar involuntariamente, proibindo o seguimento de políticas sensatas. Um dilema importante era que os tipos de medidas competitivas,

${ }^{31}$ Citado em Bambaci, Saront e Tommasi, "Economic Reforms in Argenina”, p.17. 
então necessárias para tornar viável o Plano de Convertibilidade, ofereciam ganhos mais sutis e dispersos (eficiência, produtividade), enquanto o transtorno do ajuste (desemprego, falência) era mais concentrado. Como o cenário econômico durante o segundo mandato de Menem se tornou mais deflacionário e volátil, com crescimento anual pulando de $-4,6 \%$, em 1995 , para $8,4 \%$ em 1997 , e de volca a $-3,2 \%$ em 1999, aquelas bases de coalizão que tinham apoiado a primeira fase da estabilização econômica se deterioraram ainda mais. As vitórias da oposição, em 19961997, tinham provado o fato de que o acordo de um currency board pode, na verdade, requerer um controle político maior e mais sofisticado para aprofundar e sustentar a coalizão dominante, sob circunstâncias econômicas inevitavelmente mutáveis. Mas os danos já haviam sido feitos, já que as perdas eleitorais tinham desencadeado uma batalha de sucessão prematura dentro do grupo peronista.

Como a liderança do governo diminuía, pouco se fez realmente no curso da reforma contínua de mercado durante o segundo mandato de Menem. Tudo isso se tornou mais aparente quando, no centro da recessão exorbitante de 1999 na economia real, foi o governo que perdeu a oportunidade de procurar soluções viáveis. Com medo de aumentar o nível de pressão do ajuste, já elevado, e centrado na política interna dos partidos, o melhor que o governo Menem pôde fazer foi aprovar uma lei de reforma trabalhista que não agradou a ninguém. A lei basicamente incentivava a prática de um mercado de trabalho duplo, deixando alguns trabalhadores altamente protegidos e outros tendo que se defender por si mesmos. A classe trabalhadora estava insatisfeita com o caráter de tudo ou nada da lei, e o setor privado objetou, argumentando que a lei não era garantia suficiente de custos mais baixos para o empresariado. Como se sabe, esse impasse foi resolvido um ano depois pelos sucessores de Menem, mas novamente salientou os desafios que os países de toda a região têm que enfrentar, quando líderes políticos e econômicos procuram aprofundar as reformas de mercado em andamento.

Um resultado positivo da desvalorização brasileira e da recessão resultante foi que tanto a classe trabalhadora quanto os produtores internos na Argentina sinalizaram uma disposição maior para cooperar no projeto de políticas direcionadas à promoção da competitividade. A mão-de-obra organizada respondeu de duas maneiras principais à sua frustração com o segundo governo de Menem e às suas perdas de posição no mercado. Aquelas facções que eram principalmente afetadas pelas dispensas de funcionários e cortes nas empresas se tornaram cada vez mais reivindicadoras de níveis mais adequados de assessoria ao ajuste. Porém um segmento bastante grande da mão-de-obra organizada também procurou adaptar-se à reestruturação de mercado, negociando critérios de flexibilidade e produtividade e através da participação nessas atividades relacionadas com a privatização, tais como participação dos empregados e opções de compra de ações. ${ }^{32}$ Os produtores

\footnotetext{
${ }^{32}$ M. Victoria Murillo, "Union Politics, Market-Oriented Reforms, and the Reshaping of Argentine Corporatism", em Douglas Chalmers e outros, The New Politics of Inequality in Latin America (Oxford University Press, 1997), pp. 72-94.
} 
internos, por sua vez, reafirmaram sua adesão ao currency board, ao mesmo tempo que voltaram a atenção para as autoridades, para que agissem mais enfaticamente, reduzindo os altos custos empresariais e facilitando o fluxo de crédito barato para o setor privado. ${ }^{33} \mathrm{~A}$ incapacidade do governo de Menem, que estava de saída, de dirigir um conjunto mais eficaz de respostas políticas sugeria que, independente da filiação partidária, era hora de passar o bastão para uma nova coalizão de reforma.

Isso nos leva à terceira fase política: a eleição presidencial de outubro de 1999 e suas consequências. ${ }^{34}$ Para surpresa de poucos, a eleição foi folgadamente vencida pelo prefeito de Buenos Aires, Fernando de la Rúa, que obteve quase 50\% do voto popular como candidato da aliança entre Partido Radical-Frepaso (Alianza Democrática). Os vencidos na corrida presidencial, o candidato peronista Eduardo Duhalde e o ex-ministro das Finanças, Domingo Cavallo, tiveram 38\% e $10 \%$ dos votos, respectivamente. Ironicamente, o único candidato que insinuava mudar substancialmente as políticas que apoiavam o currency board era o candidato peronista, que baseou sua campanha simultaneamente nos louros do Plano de Convertibilidade e no papel do Partido Justicialista de lançá-lo. Embora a retórica da campanha ambígua de Duhalde - inclusive uma proposta de curta duração para uma moratória nos pagamentos do serviço da dívida externa da Argentina e um retorno a níveis mais elevados de corporativismo e proteção comercial - lhe tenha rendido pouca simpatia por parte dos eleitores ou da comunidade financeira internacional, a perda da Presidência pelo partido peronista foi parte essencial da trajetória da economia política que vinha sendo traçada desde as eleições de 1997, ocorridas na metade do mandato de Menem.

Para resumir, a disputa intensa dentro do partido peronista, incluindo os esforços malogrados de Menem para reverter uma interdição constitucional contra um terceiro mandato consecutivo, bem como a nuvem negra da corrupção e insensibilidade à miséria social que rondava cada vez mais o governo de Menem, resultaram, em última análise, na ruína de Duhalde nas pesquisas de opinião. Embora as garantias de anticorrupção e de aprofundamento da reforma administrativa, dadas por Cavallo, fossem muito mais passíveis de credibilidade do que a imagem de "barão ladrão" dos peronistas, como arquitetos oficiais do Plano de Convertibilidade, ele também sofreu a reputação de não cuidar o bastante das questões sociais. Em compensação, De la Rúa perseverou com a mesma mensagem que tinha produzido as vitórias da oposição a partir de 1996: continuação do Plano de Convertibilidade e das políticas monetárias e fiscais fundamentais para sustentá-lo, mas também o compromisso de levar adiante, de forma mais agressiva e harmônica, o modelo econômico predominante na frente social. Especificamente, o presidente eleito garantiu combater o desemprego, propiciando um alívio maior do ajuste (por exemplo, pagamentos subsidiados de juros da dívida) para aquelas empresas de

\footnotetext{
${ }^{33}$ Ken Warn, "Presidential Initiative Pays Off: Argentina", Financial Times, 12 de março de 1999, p. 5.

34 Para mais detalhes sobre a disputa presidencial de 1999, ver William C. Smith, "The End of the Menem Era in Argentina", North-South Center Update, 25 de outubro de 1999.
} 
pequeno e médio porte que eram responsáveis pelo maior volume de empregos na Argentina, e cortar o déficit fiscal de forma que não dependesse estritamente de mais austeridade, como, por exemplo, punindo drasticamente os sonegadores fiscais e através da eliminação do desperdício e subornos governamentais..$^{35}$

A política da virada do século na Argentina reflete, em primeiro lugar, que o país percorreu um longo caminho para solucionar os tipos de estagnação que caracterizaram o período pré-reforma e, em segundo, que a estratégia inicial de proteger os encraves iliberais, por parte do governo de Menem, fazendo acordos que eram insustentáveis a longo prazo e mantendo à distância os derrotados da reforma de mercado, tinha simplesmente chegado ao fim. Agora, na esteira do choque brasileiro, uma nova equipe econômica enfrenta os desafios de mostrar um curso de crescimento sustentável, mostrando compreensão do controle da dívida externa e aumentando os níveis de produtividade do país e a competitividade geral. Em algum momento ao longo do caminho, o governo De la Rúa também terá que articular uma estratégia adequada de desenvolvimento que possa governar o modelo econômico na direção de exportações de valor agregado mais elevado e na criação de empregos muito mais dinâmicos.

Essas necessidades apenas são suficientes para diminuir qualquer lua-de-mel política, e o controle contínuo dos peronistas sobre as províncias, o Senado Federal e a Suprema Corte poderiam complicar ainda mais a situação. Em compensação, a oposição peronista já está visando a recuperação da Presidência e, por isso mesmo, tem interesse fixo em cooperar com as iniciativas de economia política que vão apoiar o modelo vigente. ${ }^{36}$ Isso fica evidente, por exemplo, no amplo apoio congressista que De la Rúa já obteve nas áreas de reforma fiscal, corte de gastos (por exemplo, reduzindo os preços dos combustíveis, pedágios das rodovias e frete das estradas de ferro) e reduzindo ainda mais o setor público.

É notável que a nova administração também tenha avançado na reforma daqueles setores aos quais os peronistas talvez estivessem vinculados politicamente, mas não a Alianza. Por exemplo, foram cortados os fluxos de receita bruta para pelo menos cinco províncias insolventes, impondo maior responsabilidade fiscal em nível subnacional, e finalmente foi aprovado um projeto de lei trabalhista mais abrangente durante os primeiros seis meses de mandato de De la Rúa. O novo Código do Trabalho descentraliza as negociações contratuais, de modo que as diferenças no tamanho da empresa e as demandas setoriais variáveis são mais bem acomodadas e estimulam os empresários a contratar mais trabalhadores com custos menores. Assim, o imposto sobre a folha de pagamento nas novas contratações reduziu de $17,5 \%$ para $12 \%$ e a negociação de boa-fé dos dois lados é agora in-

\footnotetext{
${ }^{35}$ Ver ibid.e "Argentina's Economy: Keeping the Reform Alive”, The Economist, October 23, 1999, pp. 23-6.

${ }^{36}$ William Perry, “Argentina Faces the Future”, Hemisphere 2000, 15 de março de 2000, p. 1.
} 
centivada pela eliminação da lei que regulava os velhos contratos na hipótese de falharem as negociações sobre um novo acordo. ${ }^{37}$

Em última análise, a sorte do Plano de Convertibilidade depende totalmente dos progressos feitos em atacar esse conjunto mais difícil de reformas de mercado "de segunda geração". As tarefas disponíveis são mais do que simplesmente exercícios técnicos. Agora, outros progressos com reformas de mercado vão exigir participação mais ampla e negociação de boa-fé com os setores mais atingidos, nas questões complexas que variam desde imposto adicional e reduções de custos até a implementação mais vigorosa de regras que abranjam a regulamentação, a transparência e a fiscalização. O que está em jogo é a capacidade do governo De la Rúa de perseverar em superar de forma assertiva aqueles obstáculos de ação coletiva que impediram policy makers e os líderes políticos de enfrentar as barreiras restantes contra a produtividade, eficiência e maior igualdade na economia argentina.

\section{CONCLUSÃO}

Este capítulo se iniciou perguntando por que a Argentina permaneceu num regime monetário de taxa fixa quando todos os seus vizinhos de mercado emergente se dirigiram para a flexibilidade cambial. Como geralmente acontece nessas questões, a pergunta é muito mais simples do que a resposta. O histórico positivo da última década mostra que a decisão original de fixar o peso com base no dólar norte americano foi uma decisão acertada, dada a perda total de credibilidade da Argentina em 1991. No entanto, como também mostra a análise, as condições econômicas que dão base ao currency board mudaram acentuadamente ao longo do tempo. Ao implementar um conjunto ambicioso de reformas de mercado, conjuntamente com o Plano de Convertibilidade, a Argentina aumentou dramaticamente seu nível de abertura econômica, assim como sua exposição a altos níveis de dívida externa e mobilidade de capital internacional nos anos 90.

A experiência dos três outros países estudados neste livro foi de uma flexibilidade cambial maior para facilitar mais o ajuste e mitigar o impacto potencialmente grande da volatilidade internacional. A resistência da Argentina a essa mesma transição talvez seja mais bem entendida no contexto da economia política interna. Períodos contínuos de crescimento e prosperidade econômicos provaram ser ilusórios na Argentina, particularmente se comparada aos outros países analisados neste volume. A hiperinflação do passado mais recente fora a gota d'água, deixando os policy makers e a opinião pública em geral extremamente relutantes em arriscar a mudança de uma taxa de câmbio fixa que finalmente estabilizou a economia. Porém, por causa da rápida recuperação do México, sob uma taxa flutuante desde 1995, e do ponto de inversão inesperadamente precoce do Brasil depois de ter mudado para um regime monetário semelhante, no início de 1999, há uma chance

${ }^{37}$ Ver J. P. Morgan, “Data Watch: Argentina”, Global Data Watch, 28 de abril de 2000, p. 29. 
aparente de que a história esteja se repetindo. Ao atar propositadamente suas mãos a um currency board, as autoridades políticas argentinas renunciaram às ferramentas fiscais e monetárias mais básicas que ajudaram a estimular a recuperação econômica nesses outros países. O futuro do currency board pode ser bom, mas a credibilidade do programa de reforma da Argentina vai sofrer se o país continuar a depender de medidas altamente recessivas e da obtenção de empréstimos externos excessivos para garantir sua sobrevivência.

Quais as lições que o caso da Argentina traz para os debates sobre as taxas de câmbio fixas contra as flexíveis? Em primeiro lugar, parece que manter uma moeda forte não significa necessariamente ter uma economia forte. Como esta análise mostrou, apesar da suposta invencibilidade do Plano de Convertibilidade e dos avanços heroicos no âmbito da disciplina fiscal e da profunda reforma do setor financeiro, a economia da Argentina ainda está cheia de falhas relacionadas à eficiência, produtividade e competitividade comercial. Uma segunda lição, além dessa, é que a credibilidade de um determinado programa de reforma pode ser um alvo móvel - especialmente num mundo de alta mobilidade de capital. É questionável, por exemplo, se o compromisso do governo Menem de "dolarizar antes de desvalorizar" aumentou sua credibilidade. De faro, esse gesto chama ainda mais a atenção da opinião internacional sobre as fragilidades da economia argentina, sugerindo a necessidade de taxas de juros internas mais elevadas e de obtenção de mais empréstimos para aumentar a credibilidade.

Finalmente, como Timothy Kessler e Eliana Cardoso salientaram em seus capítulos, simplesmente não resultaram em nada as argumentações bem-feitas no México e Brasil da pré-desvalorização acerca da rapidez com que os ganhos de produtividade no setor de bens comerciáveis iriam compensar a valorização da taxa de câmbio real. Em vez disso, como Cardoso observa, a "auto-ilusão do governo acarretou um compromisso cada vez mais oneroso para garantir um resultado insustentável”. Como o governo De la Rúa continua a garantir sua total adesão ao Plano de Convertibilidade, é preciso ver se a Argentina será capaz de enfrentar essas difíceis desvantagens. Parece, ao menos, que policy makers e legisladores deram o passo para o lançamento dos tipos de políticas que serão essenciais para fortalecer a confiança do mercado e melhorar a competitividade.

Em termos da economia política da reforma de mercado na Argentina, vale a pena reiterar duas outras lições da era Menem. Primeira, apesar da aparente simplicidade do currency board e do estilo de gestão descompromissada que ele implica, o mesmo não se pode dizer das estratégias políticas necessárias para apoiá-la. De fato, uma taxa de câmbio fixa sempre criou pressões maiores para a administração política mais intensiva e flexível, já que os representantes nacionais foram forçados a ajustar-se às demandas impostas pelo Plano de Convertibilidade.

A segunda lição é que as tendências eleitorais desde 1996 confirmam que uma coalizão política para apoiar a reestruturação em nível micro na Argentina não flui naturalmente das mesmas alianças que promoveram a estabilização macroeconômica e o lançamento de reformas de mercado fundamentais (liberalização, privatização, desregulamentação). O tipo de grande aliança eleitoral que possibilitou a 
coalizão Radical-Frepaso para conseguir a Presidência talvez seja considerada melhor como uma estratégia política provisória para vencer esse desafio. Embora não vinculado aos mesmos interesses trabalhistas e provinciais que obstruíram toda a implementação do pacote de reforma peronista, o governo De la Rúa enfrenta os desafios à sua capacidade de governar em virtude das diversas reivindicações que estão em sua base. ${ }^{38}$ Embora a Alianza Democrática esteja começando bem, ainda tem pela frente a difícil tarefa, mas não impossível, de sedimentar uma coalizão política para enfrentar toda a gama de reformas em nível micro.

\footnotetext{
${ }^{38}$ Comentários feitos por Juan Corradi no workshop sobre "Post-Reform Elections in Latin America", School of Advanced International Studies (SAIS), Universidade Johns Hopkins, Washington, D.C., 4 de março de 2000 .
} 